\title{
Care coordination and longitudinality in primary health care in the Brazilian Amazon
}

\author{
Coordenação e longitudinalidade da atenção primária à saúde na Amazônia brasileira \\ Coordinación y longitudinalidad del cuidado en la atención primaria de salud en la Amazonia brasileña
}

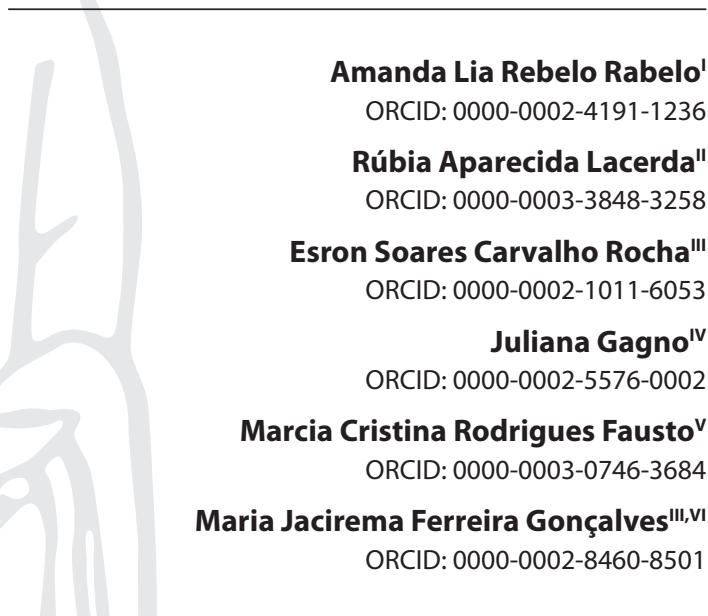

'Fundação de Medicina Tropical. Manaus, Amazonas, Brazil.

"Universidade de São Paulo. São Paulo, São Paulo, Brazil. "'Universidade Federal do Amazonas. Manaus, Amazonas, Brazil. " Universidade Federal do Oeste do Pará. Santarém, Pará, Brazil. ${ }^{\vee}$ Fundação Oswaldo Cruz. Rio de Janeiro, Rio de Janeiro, Brazil. v'Fundação Oswaldo Cruz. Manaus, Amazonas, Brazil.

How to cite this article:

Rabelo ALR, Lacerda RA, Rocha ESC, Gagno J, Fausto MCR, Gonçalves MJF. Care coordination and longitudinality in primary health care in the Brazilian Amazon. Rev Bras Enferm. 2020;73(3):e20180841. doi: http://dx.doi.org/10.1590/0034-7167-2018-0841

Corresponding author: Maria Jacirema Ferreira Gonçalves E-mail: jaciremagoncalves@gmail.com

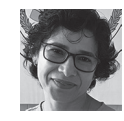

EDITOR IN CHIEF: Dulce Aparecida Barbosa ASSOCIATE EDITOR: Dulce Aparecida Barbosa

Submission: 11-06-2018

Approval: 07-08-2019

\begin{abstract}
Objectives: to evaluate the attributes of primary health care, care coordination and longitudinality, from the perception of the professional and patients in the state of Amazonas, Brazil. Methods: quantitative evaluative study, in which was used an external evaluation instrument with 469 professionals and 1,888 patients from 367 primary health care facilities that adhered to the Program for Improving Access and Quality of primary health care (Portuguese acronym: PMAQ) standardized by the Ministry of Health. Data were grouped by multivariate cluster analysis in order to find a classification of primary health care from the perspective of professionals and patients. Results: the attributes of coordination and longitudinality are still expressed in a weak and undeveloped way in the Brazilian Amazon scenario. Conclusions: it is necessary to recognize the organizational barriers and what could promote conditions for the performance of health care teams in the perspective of a continuous, integral and coordinated care.

Descriptors: Primary Health Care; Integrality in Health; Continuity of Patient Care; Health Evaluation; Health Policy.
\end{abstract}

\section{RESUMO}

Objetivos: avaliar os atributos da atenção básica, longitudinalidade e coordenação do cuidar, a partir da percepção do profissional e dos pacientes no estado do Amazonas, Brasil. Métodos: pesquisa avaliativa quantitativa em que foi utilizado um instrumento de avaliação externa com 469 profissionais e 1.888 pacientes de 367 unidades básicas de saúde, que aderiram ao Programa de Melhoria de Acesso e Qualidade da Atenção Primária à Saúde padronizados pelo Ministério da Saúde do Brasil. Os dados foram agrupados por análise multivariada de cluster para encontrar uma classificação da atenção primária à saúde sob o ponto de vista de profissionais e pacientes. Resultados: os atributos de coordenação e longitudinalidade ainda são expressos de forma fraca e pouco desenvolvida no cenário da Amazônia brasileira. Conclusões: é necessário reconhecer as barreiras organizacionais e o que pode promover condições para que as equipes de atenção primária à saúde atuem sob a perspectiva de um cuidado contínuo, integral e coordenado.

Descritores: Atenção Primária à Saúde; Integralidade em Saúde; Continuidade da Assistência ao Paciente; Avaliação em Saúde; Política de Saúde.

\section{RESUMEN}

Objetivos: evaluar los atributos de atención primaria de salud, longitudinalidad y coordinación del cuidado, a partir de la percepción del profesional y los pacientes en el estado de Amazonas, Brasil. Métodos: investigación evaluativa cuantitativa en la que se utilizó un instrumento de evaluación externa con 469 profesionales y 1.888 pacientes de 367 centros de atención primaria de salud, que se adhirieron al Programa de Mejora del Acceso y Calidad de la atención primaria de salud estandarizado por el Ministerio de Salud de Brasil. Los datos se agruparon por análisis de grupos multivariados de cluster para encontrar una clasificación de la atención primaria de salud desde el punto de vista de profesionales y pacientes. Resultados: los atributos de coordinación y longitudinalidad todavía se expresan de manera débil y poco desarrollado en el escenario de la Amazonia brasileña. Conclusiones: es necesario reconocer las barreras organizativas y lo que puede promover las condiciones para que los equipos de atención primaria de salud actúen desde la perspectiva de una atención continua, integral y coordenada.

Descriptores: Atención Primaria de Salud; Integralidad en Salud; Continuidad de Atención al Paciente; Evaluación en Salud; Política de Salud. 


\section{INTRODUCTION}

Primary care is the key element of health care systems and addresses the main health problems of the population. Due to demographic differences, primary health care $(\mathrm{PHC})$ even gains in importance, and a multitask health team in defined territories aims to solve the most common problems in an integral and integrated way in conjunction to other network spots. Its action is complex and should be further explored for the improvement of professional practices in order to promote health and avoid illness.

Care coordination is an essential attribute of PHC systems in the provision of comprehensive healthcare through practices that ensure the continuity of care. The objective of coordination mechanisms is to facilitate the integration between professionals and services, and offer a continuous, lasting and comprehensive health care, aspects that configure longitudinal care ${ }^{(1)}$.

Longitudinality involves three dimensions, namely: information, longitudinality and interpersonality ${ }^{(2)}$. Interpersonal and longitudinal continuity are the aspects most directly related with bonding between professionals and patients, a major element to guarantee comprehensive care.

The bond between professionals and population favors the recognition of their reference in the primary care within the health system, and makes the health service a satisfactory and usual source of health care to the needs of the population ${ }^{(3)}$. It also favors the professional-patient relation that involves reliance on the team and reference for health care at the same time that the team assumes the responsibility for care over time ${ }^{(2)}$.

In Brazil, the term adopted in the Brazilian Policy for Primary Care (Portuguese acronym: PNAB) to designate PHC is Basic Care. It covers acts of promotion, prevention and health care to the most frequent problems in territories where the population is linked to the PHC team. The attributes are expressed through communication tools and organization of health care, which help the monitoring of health problems ${ }^{(4)}$.

The Program for Improving Access and Quality of primary health care (Portuguese acronym: PMAQ) was structured to induce the $\mathrm{PHC}$ quality according to the guidelines proposed in the Brazilian Policy for Primary Care. Therefore, it is an important source of research on evaluation ${ }^{(5-6)}$, and its data were used in this study.

\section{OBJECTIVES}

To evaluate the attributes of primary health care, care coordination and longitudinality from the perception of the professional and patients in the state of Amazonas, Brazil.

\section{METHODS}

\section{Ethical aspects}

The Research Ethics Committee approved this research project, and all interviewed subjects signed the Informed Consent form.

\section{Design, setting and study period}

This is an evaluative study on care coordination and longitudinality in PHC in the state of Amazonas. Participants of the study were 469 professionals and 1,888 patients from 367 Basic Health Units in 60 out of 62 municipalities in the state of Amazonas that adhered to the PMAQ (cycle 2). Data were collected between 2013 and 2014 and corresponded to three modules: structure of health facilities, professionals of the health team and health service users.

\section{Population or sample}

The sample of 469 professionals included all teams that participated in the study. Each team should have a professional with bachelor degree (data from module II) nominated by the team, and four patients (data from module III) who attended the service to any treatment during the study period, according to recommendations stated in the $\mathrm{PMAQ}^{(7)}$. This resulted in a total of 1,888 patients and there were no registered refusals in this study.

\section{Study protocol}

For developing the study, were selected variables that corresponded to the attributes pf $\mathrm{PHC}$ by considering the existing actions in the organization of PHC teams, as described below:

- Coordination of care - follow-up: actions performed by the health team for offering comprehensive care to specific priority groups; referral: mechanism for the integration of different professionals and services for offering continuity and integrality of care in the health care network.

- Longitudinality - scheduling: the form of organizing the regularly available health actions in $\mathrm{PHC}$ services to the population in a defined territory; visits and homecare: performance of homecare from the necessities spotted on the population under responsibility of the team; user satisfaction: the existence of mechanisms for promoting greater listening and participation of patients in the health care process.

The data collection instrument was a PMAQ External Evaluation Survey Form, cycle 2, standardized by the Basic Health Care Department from the Ministry of Health ${ }^{(8)}$.

In order to identify variables that fit with the thematic of this study, was performed an exploratory analysis and the variables were grouped by programmatic items and work organization items, which were: women's health, children's health, chronic diseases, tuberculosis/leprosy, home care, medical referrals, follow-up and patient satisfaction. The descriptive analysis of frequency and percentage of affirmative answers in the questionnaire were performed.

\section{Analysis of results and statistics}

The percentages of each variable by thematic of care coordination and longitudinality were grouped from the professional's declaration and patients' perception. The non-hierarchical cluster analysis (k-medians and k-means) was performed after identifying the inadequacy of hierarchical analysis from the clustergram ${ }^{(9)}$. In this method, similar variables are grouped, and the mean (normal data) and median (non-normal data) are used as a method of partition and grouping according the Shapiro-Wilk normality test. In cluster analysis, the closer percentages were grouped according the Euclidean distance (declarations of the PHC team) or the square 
of the Euclidean distance (patients' perception). The Stata 9.0 program was used for the analysis.

The amount of $k$ clusters was defined from the inspection of the clustergram, in which the variables were grouped in clusters and then plotted on the graph in order to identify in which clusters occurred the most heterogeneous and epidemiologically interpretable grouping through the tabulation of means and median of each cluster from the analyzed variables.

After the inspection of each cluster, names that qualify each group were assigned heuristically, as follows: "Weak", "Regular", "Good" and "Very good". Then, were presented the mean or median percentage, the amount of variables in each grouping and the respective classification.

As the groupings were formed by variables with the same dimension (percentage ranging from 0 to 100 and always with the same amount of teams), these were used without standardization, therefore, the variance characteristics were not lost.

\section{RESULTS}

In the following dimensions, are presented two clusters for the answers of professionals: coordination of care (Figure 1-A) with 38 variables; and longitudinality (Figure 1-B) with 16 variables. In patients' perception, the dimensions of care coordination and longitudinality were grouped (Figure 1-C) with 20 variables.

The clustergrams are on the left of Figure 1 (one for each dimension), where the cut-off point of clusters is on the vertical. On the right side of Figure 1, are the distribution of the number of variables is displayed in each cluster and the qualifying denomination of the cluster according the percentage. Therefore, the height of the bar refers to the percentage reached and the number of the bar is the amount of variables grouped in that cluster.

In Figures 1-A and 1-B, is observed that most variables are classified in the "Regular" cluster, followed by the "Good" cluster, which totalizes $68 \%$ of variables in the first case (Figure 1-A), and $75 \%$ in the second case (Figure 1-B). In Figure 1-C, most variables are classified in the "Weak" cluster, followed by the "Regular" cluster, corresponding to $75 \%$ of variables related to patients' perception.

In Table 1, are shown the variables of Care Coordination in the following themes: women's health, children's health, chronic diseases, tuberculosis/leprosy and referral to specialized clinics.

In women's health, the offer of services and referral of pregnant women at risk had a "Regular" classification. The record of altered cytopathological examinations was classified as "Weak", and the cytopathological examination was classified in the "Good" cluster. Regarding children's health, the activities related to records and to children's health booklet and vaccination were both classified in the "Good" cluster. Most activities of active search were classified as "Regular". The performance of the care routine and the survey of schoolchildren with needs were in the "Weak" cluster.

In relation to chronic diseases, the consultation with cardiologist in less than 30 days is uncommon (Regular). The monitoring
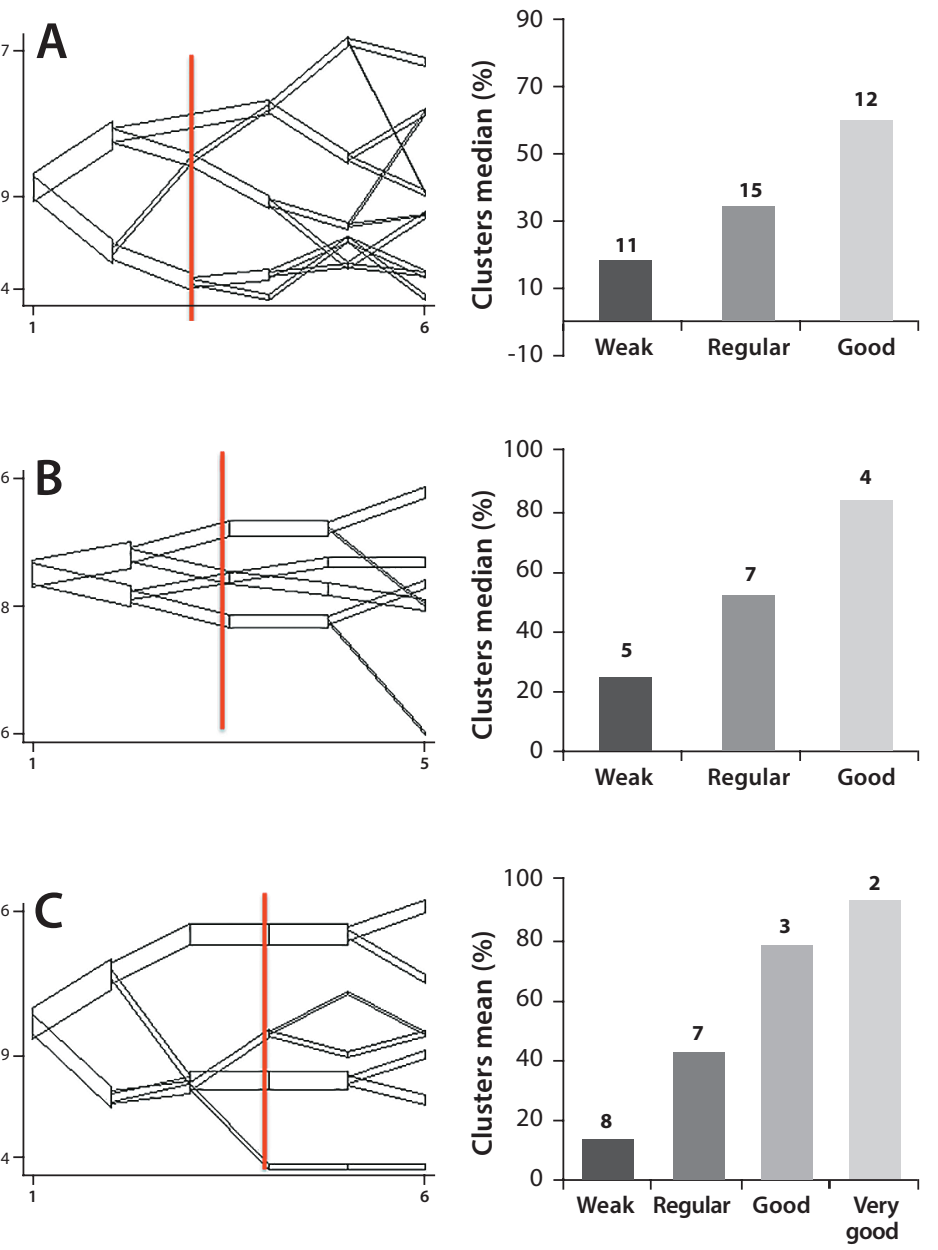

Figure 1 - Clustergrams and distribution of variables in clusters of Primary Health Care teams. Manaus, Amazonas, Brazil (2014). A- Coordination of Care declared by rofessionals. B- Longitudinality declared by professionals. C- Care Coordination and Longitudinality in the patients' perception. Source: Program for Improving Access and uality of Primary Health Care (PMAQ), cycle 2, 2014.

of hypertensive and diabetic patients (Good cluster) is performed by $92.5 \%$ of teams, but the scheduling of exams and consultations for these patients according to risk and vulnerability was classified as "Regular", as well as the guarantee of performing the fundoscopy used for eye health monitoring in diabetic patients.

In Table 2, are the Longitudinality variables that involve the schedule and visitation/homecare planning and patients'satisfaction. In the schedule planning, only $27.9 \%$ of the teams (Weak) provide space on the schedule for patients showing the results of exams for the professionals. The schedule availability for the clarification of patients' doubts and the available schedule for consultation of people in psychic suffering in any day and time of the week were classified in the "Regular" cluster. In contrast, the professionals reported they guarantee the scheduling of consultations for patients who are not seen in the same day (Good cluster).

Table 3 displays the variables of care coordination and longitudinality according to patients' perception, and includes activities related to follow-up, referral, patient satisfaction, visitation, homecare, schedule, scheduling and time to schedule appointments.

Low variability was detected in care coordination: the variables indicate the follow-up, referral and planning were classified as 
"Weak". In longitudinality, the variables that indicate approval of users with the time of professional consultation were classified as "Good" and "Very good". However, the variables related to the availability of the same professional who served patients in PHC being able to clarify doubts after the consultation, and if users are asked about their relatives, were classified in the "Regular" cluster. In relation to homecare, if users receive a visit from other professionals of the health team (except the Community Health Agent), the frequency of patients' responses was only $13.2 \%$ (Weak).

Table 1 - Care coordination activities declared by the Primary Health Care team according to thematic subgroups, Manaus, Amazonas, Brazil, 2014

\begin{tabular}{lclll}
\hline Care coordination & $\begin{array}{c}\text { Health teams } \\
n=469\end{array}$ & $\%$ & Cluster \\
\hline
\end{tabular}

Women's health

Performs cytopathological examination

Performs active search for delayed cytopathological examination

Ensures puerperal consultation up to 10 days after childbirth with visit of the community

health agent or any team member

Ensures puerperal consultation up to 10 days after childbirth with consultation at special time in any day of the week

Organizes service offers and referrals of pregnant women classified by risk and vulnerability

Records altered cytopathological examinations

401

85.5 Good

57.6 Good

Children's Health

Keeps updated records of children up to two years old

Performs active search of children under two years old

Records the growth and development of children

Records the nutritional status of children

Performs active search of children with delayed vaccine calendar

Records timely vaccination of children

Performs active search of premature children

Performs active search of underweight children

Performs active search of children with delayed childcare consultation

Records the heel-stick test in children

Proves the records of activities performed at schools

\begin{tabular}{lccc}
\hline Care coordination & $\begin{array}{c}\text { Health teams } \\
\mathbf{n}=\mathbf{4 6 9}\end{array}$ & $\%$ & Cluster \\
\hline $\begin{array}{l}\text { Records family violence in } \\
\text { children }\end{array}$ & 77 & 16.4 & Weak \\
$\begin{array}{l}\text { Records the accidents of children } \\
\begin{array}{l}\text { Performs care routine of } \\
\text { schoolchildren }\end{array}\end{array}$ & 69 & 14.7 & Weak \\
$\begin{array}{l}\text { Has records of the number of } \\
\text { schoolchildren with needs }\end{array}$ & 151 & 32.2 & Weak \\
& 122 & 26.0 & Weak
\end{tabular}

Chronic diseases

Monitors people with systolic hypertension and diabetics

Schedules consultation and examination of hypertensive and diabetic people by risk and vulnerability

Ensures cardiologist consultation in less than 30 days

Ensures fundoscopy in less than 30 days

Tuberculosis/Leprosy

Records the number of patients with tuberculosis

Proves to provide the patients' directly observed treatment for tuberculosis

Proves to provide the active search of missing patients of directly observed treatment for tuberculosis

Proves the record of the number of patients with leprosy

Proves the treatment follow-up of leprosy patients

Proves the record of active search for missing patients of directly observed treatment for leprosy

Referral

Specialized consultations

Proves keeping the record of higher risk patients referred to other health care facilities

Refers children with problems to ophthalmologic evaluation

Coordinates the referrals for specialized clinics

Refers patients at higher risk to other health care facilities

29.2 Weak

Performs follow-up of patients until receiving the specialists evaluation feedback
Refers children with problems to evaluation with an otorhinolaryngologist
7

15.6 Weak 
When aggregating all dimensions, there were 74 variables, of which 24 (32\%) were classified in the "Weak" cluster, 29 (39\%) were in the "Regular" cluster, 19 (26\%) were in the "Good" cluster, and two (3\%) variables were in the "Very good" cluster.

Table 2 - Longitudinality activities declared by the Primary Health Care team according the groups of schedule, visitation, homecare and patient satisfaction, Manaus, Amazonas, Brazil, 2014

\begin{tabular}{lcll}
\hline & $\begin{array}{c}\text { Health } \\
\text { teams } \\
n=469\end{array}$ & $\%$ & Cluster \\
Longitudinality & & \\
\hline
\end{tabular}

\section{Schedule}

Guarantees the scheduling of

consultation for patients who could not

be seen in the same day

Has free space on the schedule to clarify

patients' post-consultation doubts

Has consultation schedule for people in psychic suffering in any time of the week

Proves having reserved space on the schedule for patients showing the exam results for the professionals

$415 \quad 88.5 \quad$ Good

199

42.4 Regular

$215 \quad 45.8$ Regular

$131 \quad 27.9 \quad$ Weak

Visitation and homecare

Keeps the schedule organized for homecare

Schedules the visitation of community health personnel according to priorities of the whole team

Proves the records of the number of bedridden patients

Proves the survey of patients who need homecare

Proves the protocols with definition of priorities for homecare

Patient satisfaction

Considers the opinion of users for the reorganization and qualification of the work process

Performs user satisfaction survey

Has communication channels for recording the opinion and suggestion of users

Refers the demands to municipal secretariat

Proves the existence of local councils or other spaces of popular participation

\begin{tabular}{|c|c|c|c|}
\hline Care coordination & $\begin{array}{c}\text { Health } \\
\text { teams } \\
\mathbf{n}=\mathbf{1 8 8 8}\end{array}$ & $\%$ & Cluster \\
\hline $\begin{array}{l}\text { Can schedule consultations in the health } \\
\text { clinic with other professionals when } \\
\text { necessary }\end{array}$ & 332 & 17.6 & Weak \\
\hline $\begin{array}{l}\text { Finds easy access to talk about their } \\
\text { exams results }\end{array}$ & 921 & 48.8 & Regular \\
\hline $\begin{array}{l}\text { Has the next appointment scheduled after } \\
\text { the consultation (women's health) }\end{array}$ & 110 & 5.8 & Weak \\
\hline $\begin{array}{l}\text { Has the next appointment scheduled after } \\
\text { the consultation (hypertensive patients) }\end{array}$ & 117 & 6.2 & Weak \\
\hline $\begin{array}{l}\text { In prenatal care, always or most of the } \\
\text { times leaves with the next consultation } \\
\text { scheduled. }\end{array}$ & 202 & 10.7 & Weak \\
\hline $\begin{array}{l}\text { Was oriented about the maternal facility } \\
\text { where they would deliver }\end{array}$ & 220 & 11.6 & Weak \\
\hline \multicolumn{4}{|l|}{ Longitudinality } \\
\hline $\begin{array}{l}\text { Considers the consultation time with the } \\
\text { doctor is sufficient }\end{array}$ & 1476 & 78.2 & Good \\
\hline $\begin{array}{l}\text { Considers the consultation time with the } \\
\text { nurse is sufficient }\end{array}$ & 1708 & 90.5 & Very Good \\
\hline $\begin{array}{l}\text { In this unit, has the same doctor available } \\
\text { after service }\end{array}$ & 886 & 46.9 & Regular \\
\hline $\begin{array}{l}\text { In the unit, has the same nurse available } \\
\text { after service }\end{array}$ & 1018 & 53.9 & Regular \\
\hline $\begin{array}{l}\text { Professionals of the family team call you } \\
\text { by your name }\end{array}$ & 1806 & 95.71 & Very Good \\
\hline $\begin{array}{l}\text { Professionals of the family team ask you } \\
\text { about your relatives }\end{array}$ & 578 & 30.6 & Regular \\
\hline $\begin{array}{l}\text { Consider it is easy to clarify doubts with } \\
\text { the professionals who cared for you }\end{array}$ & 666 & 35.3 & Regular \\
\hline $\begin{array}{l}\text { You are contacted when treatment is } \\
\text { interrupted for whatever reason or to } \\
\text { know what happened and return to } \\
\text { treatment }\end{array}$ & 326 & 17.3 & Weak \\
\hline $\begin{array}{l}\text { Feels comfortable, always or most of } \\
\text { times, to talk to the health team about } \\
\text { your worries. }\end{array}$ & 1404 & 74.4 & Good \\
\hline $\begin{array}{l}\text { Receives home visits from the community } \\
\text { health agent }\end{array}$ & 1514 & 80.2 & Good \\
\hline $\begin{array}{l}\text { Always receives home visits from other } \\
\text { health team professionals }\end{array}$ & 249 & 13.2 & Weak \\
\hline $\begin{array}{l}\text { You are asked about food, leisure, physical } \\
\text { exercise, problems with drugs and } \\
\text { violence, besides the main complaint }\end{array}$ & 666 & 35.3 & Regular \\
\hline
\end{tabular}

\section{DISCUSSION}

Care coordination in PHC reflects the capacity to coordinate the actions within PHC itself, at other care levels or in institutions corresponding to other public policies involved in the care process. It is related to the continuity of care between professionals and services involved in the follow-up of clinic cases through informational and communication tools, and to the existence of referrals/flows between services ${ }^{(10-11)}$.

The results found in this study demonstrated that PHC teams in the state of Amazonas provide care to specific priority groups, as recommended by the Brazilian Policy for Primary Care ${ }^{(4)}$. This 
reinforces an important limitation regarding the routine followup of cases at higher risk, and difficulties are even greater when the therapeutic project requires referrals to shared follow-up care with other professionals and specialized clinics.

It is noteworthy that in few cases, the percentage of affirmative response regarding the performance of actions inherent to $\mathrm{PHC}$ reaches at least $90 \%$, since according to the established protocols, all activities evaluated here should be performed completely, as recommended by the Brazilian Policy for Primary Care. This certainly compromises the role of PHC as an organizer of the Health System, which could guarantee the comprehensive approach based on health necessities in a programmatic way of performing health care delivery ${ }^{(1)}$.

Although some activities related to care coordination of women's health and children's health were classified in the "Good" cluster, other underdeveloped activities might compromise the effectiveness of care, especially the care coordination in consultation, the guarantee of women's examinations and the active search for children according to their needs. The effective care coordination can integrate health services and users with the healthcare network ${ }^{(12)}$.

The performance of examinations without proper record of altered results, and the non-performance of active search are contradictory, since most teams claim to keep the follow-up. These are some of the activities that demonstrate the care coordination through communication, and the longitudinality for the easy follow-up when there is a professional-patient relationship ${ }^{(13)}$. Nevertheless, it is not possible to affirm if most variables were classified in the "Weak" and "Regular" clusters, because of the lack of municipal health network structure or because of the organization of health teams themselves.

In the literature, longitudinality commonly appears as a synonym of continuity, but the longitudinality term in the sense of relationship is more appropriated, because it does not depend on continuity to exist ${ }^{(1)}$. Continuity could be a feature both of specialized care and PHC, and it would not be oriented to people's health care, but to health problems ${ }^{(14-15)}$.

In the case of PHC facilities in the state of Amazonas, the organization of services as proposed by PHC policy guidelines is not sufficient to guarantee the provision of care that promotes the longitudinal bond and consequently, the implementation of comprehensive health care.

The teams claim to organize the priority order for home visits and the user satisfaction survey. However, the use of protocol is low, as well as surveys of risk classification, priority or frequency of home visits, and even books for users' opinion, which makes it difficult to achieve longitudinality.

In this evaluation, the features of longitudinality and care coordination in PHC in Amazonas are implemented in a scarce and fragmented way, since most were classified in the "Regular" cluster. The poor performance of essential activities for the proper functioning of $\mathrm{PHC}$ as defined in the Brazilian Policy for Primary $\mathrm{Care}^{(4)}$ reflects on the low resolution of $\mathrm{PHC}$ in Brazil(16). The dissociation between planning, health service organization and patient follow-up may also reflect on the "Weak" or "Regular" cluster classification of these attributes. As the questioned activities are based on the Brazilian Policy for Primary Care and foreseen within the role of professionals, a high percentage of teams fulfilling this role would be expected. The features of PHC are independent actions, because without longitudinality and care coordination, the professional-patient bond loses much of its potential and the other features become merely administrative functions ${ }^{(11-12)}$.

The attributes of coordination and longitudinality are related to integrality, because they contribute to the performance of comprehensive health care. At the same time, care coordination requires a longitudinal, consistent and reliable relationship between patients and professionals that ensures care in which the personal and social context of patients is taken into consideration. Thereby, the implementation of these attributes transcends multiple episodes of responsibility that permeate $\mathrm{PHC}^{(2)}$.

From patients' perception, care coordination and longitudinality do not substantially differ from the professionals' response, and were mostly classified in the "Weak" cluster. Although users recognize they are called by name, receive visits from Community Health Agents and consider the time of medical and nursing consultations as satisfactory, when asked about more relational aspects and those of patient follow-up, was identified a certain distance in relationships that might reflect on patients' level of distrust in the professional/team.

The well-known turnover of PHC team professionals may difficult the care coordination and longitudinality ${ }^{(17)}$, since these attributes are correlated to bonding ${ }^{(12)}$. The time aspect in the professional-patient relationship may determine the acceptability, recognition and health action development ${ }^{(12,17-18)}$. Inherent problems to professional practice in $\mathrm{PHC}$, such as accumulation of activities, lack of resources to perform their role, professional turnover, and professionals' profile ${ }^{(17,19)}$ might affect the teampatient bonding, and disfavor the implementation of teamwork organization based on planning and on the perspective of continuous and comprehensive care over time.

\section{Study limitations}

The data source used to conduct this study presents some limitations, like the awareness of professionals about visits and the scenario itself, besides unmet conditions of physical structure in the health units. However, there is contribution of the characterization and evaluation of $\mathrm{PHC}$ with secure data, which is standardized fieldwork performed by trained interviewers to observe and verify the supporting documents during evaluation. Furthermore, the electronic instrument contained embedded validation rules, systematic skips in case of not applicable questions, besides the time control of application.

\section{Public policy contribution}

The PMAQ links the result of the PHC team performance evaluation to the transfer of financial resources to the municipal manager, which may generate participants' interest in giving more positive answers to reach out better results. Despite the initial evaluation focus, most identified variables were still classified in the "Regular" cluster. Therefore, the results presented here allow evaluating the care coordination and longitudinality 
and indicating the elements that need priority and expansion by PHC professionals.

\section{CONCLUSIONS}

The PHC evaluation in the Amazon scenario revealed that in the perception of professionals and patients, care coordination and longitudinality are still expressed in a weak and underdeveloped way.

With the analysis, it was observed that PHC teams in the state of Amazonas still face limitations for the provision of comprehensive care, and there are persistent organizational barriers for the effectiveness of care coordination and longitudinality. The implementation of these attributes was largely classified in the "Regular" and "Weak" clusters, which is far from ideal. In other words, there is a latent need to maintain strategies for the qualification of work processes, as well as to delineate new confrontations to what hinders comprehensive health care.

For such, it is necessary to recognize what has generated the organizational barriers and what could promote conditions for the action of PHC teams towards the perspective of continuous, comprehensive and coordinated care. Qualitative studies that consider the Amazonian reality are necessary to deepen these issues.

Qualifying the organization of PHC through the attributes of longitudinality and coordination means developing actions like performing active search, keeping updated and complete records, identifying and prioritizing the most severe cases and groups of risk, planning differentiated behaviors in case of intercurrences, performing follow-up inside and outside of PHC services, in addition to using instruments focused on the communication and participation of users. This way, the concentration of efforts for improving coordination and longitudinality attributes will advance towards the benefits of PHC.

\section{REFERENCES}

1. Starfield B. Atenção primária: equilíbrio entre necessidades de saúde, serviços e tecnologia [Internet]. Brasília: Ministério da Saúde; 2002 [cited 2017 Apr 17]. Available from: http://bvsms.saude.gov.br/bvs/publicacoes/atencao_primaria_p1.pdf

2. Cunha EM, Giovanella L. Longitudinalidade/continuidade do cuidado: identificando dimensões e variáveis para a avaliação da Atenção Primária no contexto do sistema público de saúde brasileiro. Ciênc Saúde Colet. 2011;16(supl.1):1029-42. doi: 10.1590/ S1413-81232011000700036

3. Baratieri T, Teixeira Mandú EN, Marcon SS. Compreensão de enfermeiros sobre vínculo e longitudinalidade do cuidado na Estratégia Saúde da Família. Cienc Enferm. 2012;18(1):11-22. doi: 10.4067/S0717-95532012000200002

4. Ministério da Saúde (BR). Portaria n².436, de 21 de setembro de 2017. Aprova a Política Nacional de Atenção Básica, estabelecendo a revisão de diretrizes para a organização da Atenção Básica, no âmbito do Sistema Único de Saúde (SUS) [Internet]. Brasília: Ministério da Saúde; 2017 [cited 2018 Sept 05]. Available from: http://bvsms.saude.gov.br/bvs/saudelegis/gm/2017/prt2436_22_09_2017.html

5. Ministério da Saúde (BR). Portaria n 1.645, de 02 de outubro de 2015. Dispõe sobre o Programa Nacional de Melhoria do Acesso e da Qualidade da Atenção Básica (PMAQ-AB) [Internet]. Brasília: Ministério da Saúde; 2015 [cited 2016 May 12]. Available from: http://bvsms. saude.gov.br/bvs/saudelegis/gm/2015/prt1645_01_10_2015.html

6. Pinto HA, Sousa ANA, Ferla AA. O Programa Nacional de Melhoria do Acesso e da Qualidade da Atenção Básica: várias faces de uma política inovadora. Saúde Debate. 2014;38(n. esp):358-72. doi: 10.5935/0103-1104.2014S027

7. Pinto HA, Sousa A, Florencio AR. O Programa Nacional de Melhoria do Acesso e da Qualidade da Atenção Básica: Reflexões sobre o seu desenho e processo de implantação. R Eletr Com Inf Inov Saúde. 2012;6(2). doi: 10.3395/reciis.v6i2.492

8. Ministério da Saúde (BR). Departamento de Atenção Básica. Programa de Melhoria do Acesso e da Qualidade (PMAQ). Instrumento de avaliação externa para as equipes de atenção básica (saúde da família e equipe parametrizada) [Internet]. Brasília: Departamento de Atenção Básica. Ministério da Saúde; 2013 [cited 2017 Feb 21]. Available from: http://189.28.128.100/dab/docs/portaldab/documentos/ instrumento_ae_sfp.pdf

9. Schonlau M. The clustergram: A graph for visualizing hierarchical and non-hierarchical cluster analyses. Stata J [Internet]. 2002 [cited 2016 Sept 23];2(4):391-402. Available from: http://www.schonlau.net/clustergram.html

10. Almeida PF, Santos AM. Primary Health Care: care coordinator in regionalized networks? Rev Saúde Pública. 2016;50:80. doi: 10.1590/ s1518-8787.2016050006602

11. Souza MF, Santos AF, Reis IA, Santos MAC, Jorge AO, Machado ATGM, et al. Care coordination in PMAQ-AB: an Item Response Theory-based analysis. Rev Saúde Pública. 2017;51:87. doi: 10.11606/s1518-8787.2017051007024

12. Araujo JP, Viera CS, Oliveira BRG, Gaiva MA, Rodrigues RM. Assessment of the essential attributes of Primary Health Care for children. Rev Bras Enferm [Internet]. 2018;71(Suppl 3):1366-72. [Thematic Issue: Health of woman and child] doi: 10.1590/0034-7167-2017-056913.

13. Garnelo L, Lucas ACS, Parente RCP, Rocha ESC, Gonçalves MJF. Organização do cuidado às condições crônicas por equipes de Saúde da Família na Amazônia. Saúde Debate. 2014;38(n. esp):158-72. doi: 10.5935/0103-1104.2014S012

14. Giovani MSP, Vieira CM. Longitudinalidade do cuidado diante da rotatividade de profissionais na Estratégia Saúde da Família. R Eletr Com Inf Inov Saúde. 2013;7(4). doi: 10.3395/reciis.v7i4.572

15. Kessler M, Lima SBS, Weiller TH, Lopes LFD, Ferraz L, Thumé E. Longitudinality in Primary Health Care: a comparison between care models. Rev Bras Enferm [Internet]. 2018;71(3):1063-71. doi: 10.1590/0034-7167-2017-0014 
16. Silva SA, Nogueira DA, Paraizo CMS, Fracolli LA. Assessment of primary health care: health professionals' perspective. Rev Esc Enferm USP. 2014;48(n. spe):122-8. doi: 10.1590/S0080-623420140000600018

17. Seidl H, Vieira SP, Fausto MCR, Lima RCD, Gagno J. Gestão do trabalho na Atenção Básica em Saúde: uma análise a partir da perspectiva das equipes participantes do PMAQ-AB. Saúde Debate. 2014;38(n. esp):94-108. doi: 10.5935/0103-1104.2014S008

18. Sisson MC, Andrade SR, Giovanella L, Almeida PF, Fausto MCR, Souza CRP. Estratégia de Saúde da Família em Florianópolis: integração, coordenação e posição na rede assistencial. Saúde Soc. 2011;20(4):991-1004. doi: 10.1590/S0104-12902011000400016

19. Lima JG, Giovanella L, Fausto MCR, Bousquat A, Silva. Atributos essenciais da Atenção Primária à Saúde: resultados nacionais do PMAQ-AB. Saúde Debate. 2018;42(n. esp):52-66. doi: 10.1590/0103-11042018s104 